\section{Antarctic benthic diversity}

SIR - Poore and Wilson ${ }^{1}$, and Rex et al. ${ }^{2}$, give evidence for a distinct decline in species diversity in deep-sea communities from the tropics towards north polar regions; and for a less clear trend but high interregional variability in the Southern Hemisphere. Poore and Wilson ${ }^{1}$ included some isopod data from the Scotia Basin and the Weddell Sea (Atlantic sector of the Southern Ocean), but the data of Rex et al. ${ }^{2}$ are limited to regions north of $40^{\circ} \mathrm{S}$.

We computed figures for species diversity by Hurlbert's method ${ }^{3}$ for Weddell Sea bivalves, gastropods and isopods, and find that these fall in the upper range of tropical values and are distinctly higher than in north polar regions (see table), provided that diversity figures depending on Agassiz trawl samples and epibenthic sled samples are comparable. Indeed, our data indicate that there is no steady latitudinal decrease in deep-sea benthic range and of similar variability as in north polar seas ${ }^{7-9}$. Quaternary glaciation in Antarctica was as extensive as in the north polar region $^{10}$.

Hence, the tropical level of Antarctic species diversity is probably related to factors or processes unique to the Antarctic. The main differences between the Arctic and the Antarctic systems are the higher age and longer isolation of the latter. During the past 60 million years, the Antarctic experienced a slow and discontinuous transition from a warm water system in the early Tertiary $\left(15^{\circ} \mathrm{C}\right)$ to today's cold water system $(-1.8$ to $\left.2{ }^{\circ} \mathrm{C}\right)^{11}$. The first strong glaciation including shelf-ice formation had already occurred 36 million years ago in the early Oligocene $\mathrm{C}^{12}$. The formation of the circumAntarctic current about 23.5 million years ago $^{13}$ further isolated the Antarctic and its fauna from the world ocean. Most of the
SPECIES DIVERSITY IN SOUTHEASTERN WEDDELL SEA

\begin{tabular}{|c|c|c|c|c|c|}
\hline Taxon & $\begin{array}{c}\text { No. of } \\
\text { individuals }\end{array}$ & $\begin{array}{l}\text { No. of } \\
\text { species }\end{array}$ & $\begin{array}{c}E\left(S_{100}\right) \text { in the } E\left(S_{n}\right)^{*} \text { in the } \\
\text { Weddell Sea Weddell Sea } \\
\text { (this study) (this study) }\end{array}$ & $\begin{array}{l}\text { Range of } \\
E\left(S_{n}\right)^{*} \text { in } \\
\text { tropical } \\
\text { regions } \\
20^{\circ} \mathrm{N}-20^{\circ} \mathrm{S}\end{array}$ & $\begin{array}{l}\text { Range of } \\
E\left(S_{n}\right)^{*} \text { in } \\
\text { north polar } \\
\text { regions } \\
\geqslant 70^{\circ} \mathrm{N}\end{array}$ \\
\hline
\end{tabular}

$\begin{array}{lrrrrrc}\text { Bivalvia } & 190 & 26 & 20 & 17 & 3-16 & <5 \\ \text { Gastropoda } & 162 & 34 & 27 & 18 & 10-23 & <6 \\ \text { Isopoda } & 846 & 71 & 30 & 41 & 24-52 & <10 \\ \text { Amphipoda } & 1,804 & 100 & 36 & - & - & - \\ \text { Decapoda } & 13,133 & 5 & 3 & - & - & - \\ \text { Holothuroidea } & 8,284 & 22 & 9 & - & - & - \\ \text { Ophiuroidea } & 4,031 & 23 & 13 & - & - & - \\ \text { Polynoidae } & 748 & 20 & 17 & & -\end{array}$

The table shows Agassiz trawl samples (500-2,000 $\mathrm{m}$ water depth, 70-78 $\mathrm{S}$ ) compared with figures in ref. 2. For inter-taxon comparisons, we applied a normalized sample size of $n=100$.

* Normalized sample sizes used in ref. 2 are $n=75$ for bivalves, $n=50$ for gastropods and $n=200$ for isopods. $E\left(S_{n}\right)$, species diversity.

diversity towards south polar regions. But in the Weddell Sea species diversity varies by an order of magnitude among the taxa we analysed (see table). The polewards decline of species diversity in the Northern Hemisphere has been related to the inverse relation between magnitude and variability of sedimentation and species diversity ${ }^{2}$, and to the effects of Quaternary glaciation on the benthos ${ }^{4}$. However, sedimentation of organic carbon in the southeastern Weddell Sea ${ }^{5,6}$ is in the same

1. Poore, G. C. B. \& Wilson, G. D. F. Nature 361, 597-598 (1993)

2. Rex, M. A. et al. Nature 365, 636-639 (1993).

3. Hurlbert, S. H. Ecology 52, 577-586 (1971).

4. Dahl, E. Sarsia 64, 57-59(1979).

5. Bathmann, U. etal. Polar Biol. 11, 185-195 (1991)

6. Wefer, G. \& Fischer, G. Mar. Chem. 35, 597 (1991)

7. Bathmann, U. et al. Prog. Oceanogr. 24, 117-129 (1990).

8. Hebbein, D. \& Wefer, G. Nature 350, 409-411 (1991)

9. Bodungen, B.v. et al. in Sediment trap in the Northern Countries 2 (eds Wassmann, P. et al.) 116-136 (Yliopistopaino, Helsinki, 1991).

10. Quilty, P. G. in Antarctic Ecosystems - Ecological Change and Conservation (eds Kerry. K. R. \& Hempel, G.) 4-8 (Springer, Berlin, 1990). present fauna evolved within the Southern Ocean ${ }^{14}$, as indicated by high levels of endemism ${ }^{15}$ exceeding those in the Arctic, where boreo-Arctic species dominate ${ }^{16}$.

The unique glaciological history of the Antarctic and its long term isolation led to the evolution of a specific fauna well adapted to a cold water system experiencing episodic glaciation and strong seasonal as well as inter-annual variability in food input (cold stenothermy, low metabolism and eurybathy). However, the palaeonto-

\footnotetext{
11. Kennett. J. P. J. geophys. Res. 82, 3834-3860 (1977)

12. Ehrmann, W. U. \& Mackensen, A. Palaeogeogr. Palaeoclim. Palaeoecol. 93, 85-112 (1992).

13. Kennett, J. P. \& Barker, B. F. Proc. ODP Sci. Res. 113 937-960 (1990)

14. Clarke, A. in Temperature and Evolution: Southern Ocean Cooling and the Antarctic Marine Fauna (eds Kerry, K. R. \& Hempel, G.) 9-22 (Springer, Berlin, 1990).

15. White, M. G. in Antarctic Ecology Vol.2 (ed. Laws, R. M.) 421-461 (Academic, London, 1984).

16. George, R. Y. in Polar Oceans (ed. Dunbar, M. J.) 391-408 (Arctic institute of North America. Montreal. 1977).

17. Ricklefs, R. E. Science 235, 167-171 (1987).
}

logical record and present-day variation in species richness among taxa point to different levels of success in surviving recent periods of extreme glaciation ${ }^{14}$.

The high species diversity of the Antarctic slope and deep sea benthos shows the significance of regionalhistorical processes ${ }^{17}$ in the development of marine benthic communities. Thus, differences in regional history (geology, oceanography, climatology) have to be taken into account when interpreting global patterns of species diversity.

Thomas Brey, Michael Klages,

Corinna Dahm, Matthias Gorny,

Julian Gutt, Stefan Hain,

Michael Stiller, Wolf E. Arntz

Alfred Wegener Institute for Polar- and

Marine Research,

Postfach 120161,

D-27515Bremerhaven, Germany

Johann-Wolfgang Wägele

Alfons Zimmermann

Fakultät für Biologie,

Universität Bielefeld,

D-33615 Bielefeld, Germany

\section{Quantitative social science}

SIR - Double jeopardy (DJ) is a pervasive marketing phenomenon where a minor brand is often found to attract not only fewer buyers, but also ones that are less loyal. Ehrenberg ${ }^{l}$ takes the generality of DJ in many consumer settings as a first demonstration of the existence of empirical "laws" with universal regularities in social sciences. He suggests that DJ conforms with an empirical model given by a Dirichlet distribution. We propose that such a model has a sound theoretical underpinning that stems from the basic laws of probability.

For simplicity, consider two competing brands with consumer preferences (degrees of loyalty) $p$ and $q$ such that $p+q=$ 1 and $p, q$ both $\geqslant 0$. Suppose there is a total of $N$ consumers. The question is: how many of them will buy each brand? This is analogous to the classical cointossing experiment in which a loaded coin with biases $p$ and $q$ on both sides is tossed $N$ times. The random outcomes $N_{p}, N_{q}$ (=N- $N_{p}$ ) are given by the binomial distribution of the form $\mathrm{f}\left(N_{p} \mid p\right) \equiv$

$$
\left(\begin{array}{c}
N \\
N p
\end{array}\right) p^{N p}(1-p)^{N-N p} \text {. }
$$

The most likely outcomes, given by the peak of the distribution, are $N_{p}{ }^{*}=N . p$ and $N_{q}{ }^{*}=N . q$ so that $N_{p}{ }^{*}>N_{q}{ }^{*}$ if $p>q$. Thus a favourite brand necessarily yields a greater market share. Similar arguments are readily extended to situations with more than two brands or with multiple purchases from each buyer.

Conversely, suppose one observes that the market shares for two competing 